HUNGARIAN AGRICULTURAL ENGINEERING

$N^{\circ} 28 / 2015$ 19-22

Published online: http://hae-journals.org/

HU ISSN 0864-7410 (Print) / HU ISSN 2415-9751(Online)

DOI: 10.17676/HAE.2015.28.19
PERIODICAL OF THE COMITTEE OF AGRICULTURAL AND BIOSYSTEM ENGINEERING OF

THE HUNGARIAN ACADEMY OF SCIENCES and

SZENT ISTVÁN UNIVERSITY

Faculty of Mechanical Engineering

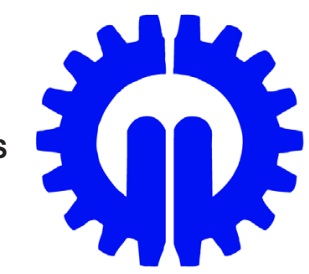

\title{
THE USE OF BIOMASS FOR ELECTRIC POWER PRODUCTION IN POLISH POWER PLANTS
}

\author{
Author(s): \\ J. Piechocki - P. Solowiej - M. Neugebauer
}

Affiliation:

Department of Electrical, Power, Electronic and Control Engineering, University of Warmia and Mazury in Olsztyn, Oczapowskiego 10, 10-736 Olsztyn, Poland

Email address:

jpt@uwm.edu.pl, pit@uwm.edu.pl, mak@uwm.edu.pl

\begin{abstract}
More than $95 \%$ of electric power in Polish power plants is produced from coal. This results in the emissions of large volumes of $\mathrm{CO} 2$ into the atmosphere, hence in some power plant alternative methods of electric power generation are being implemented. One of the many possible solutions is to produce electric power from biomass. There are two biomass options available for the power plants. One is the cogeneration of electricity from biomass and coal, and the second is firing only the biomass in the boilers.

Those solutions may be effectively applied to the production of electric power in north-western Poland, as it is a region with large forest areas and strong agricultural production. One example is the power plant in Białystok which includes a power block that produces energy only from biomass (wood), and the power plant in Ostrołęka with a cogeneration power block. This report compares those solutions from various perspectives.

The material presents a new strategy of use of different energy sources in order to optimise the energy management in the electric power system. The objective of the energy management optimisation strategy in the electric power system is to balance the capacity for the electric power production from biomass with the consumers' demand.
\end{abstract}

\section{Keywords}

biomass, electric power, power plant, cogeneration

\section{Introduction}

The organisms and their environment enter into a myriad of interactions which lead to the creation of certain ecosystems. A change in the environmental conditions disrupts the functioning of those systems and may result in adverse changes for the entire environment. The changes of the environmental conditions are triggered mainly by human activity. Therefore, the activities of humans, mostly businessrelated, must be conducted in such way as to minimize its environmental impact. This necessitates the reduction of the volume of pollution related to the production of goods necessary for human needs that is released into the environment. As evident from the experiences thus far and the conducted studies, the highest contributors to the emissions of pollution into the environment are the technologies related to the production of energy in various forms.

The limited conventional energy sources and the problems arising from the nuisance of the energy production with the use of such conventional sources, in particular the environmental hazards related to the combustion of fossil fuels, drive the search for other, alternative solutions. The increasing application of unconventional energy sources, especially the renewable ones, opens up the possibility of avoiding the aforementioned nuisances and hazards. In recent years, research on the use of such alternative energy sources has intensified around the world. The key factor is the rising awareness in the society that ca. $2 / 3$ of the pollution in the environment is directly and indirectly related to the mining and combustion of conventional energy carriers, most of all coal. It should be pointed out here that the global environment pollution has already reached its limit, therefore it is crucial to start cleaning the environment, which can be achieved i.a. by broad application of renewable energy sources. This issue has been discussed on numerous occasions in the reports of international organisations dealing with the philosophy of rational consumption of Earth's energy resources. With stateof-the-art technologies of producing energy from renewable sources, the economic relation is continuously improved as compared to conventional energy sources. That being said, it should be emphasized that the costs of the latter do not include the losses related to environment cleaning.

For environmental reasons, the structure of use of the primary carriers of energy from conventional sources plays an essential role. Compared to Western Europe, Poland is characterised by the dominant position of coal, which amounts to $76 \%$ in comparison to ca. $20 \%$ in Western European countries. In Western Europe, the structure of use of primary carriers of energy from conventional sources is dominated by oil, which amounts to $45 \%$, with below $15 \%$ in Poland. Similarly high are the shares of natural gas and nuclear power. In Poland, the latter is absent altogether from the national energy balance, while the former contributes below $8 \%$.

The result of the structure of use of the primary carriers of energy from conventional and alternative sources is the annual level of emissions into the atmosphere. The data on emissions with respect to the unit of area of the country are provided in Table 1.

The economic losses arising from the emissions caused by the consumption of fuels aggregate to several dozen percent of 
the annual national income. The comparison of the economic impacts of the emissions into the atmosphere from the sectors of economy based on the consumption of fuels is provided in Table 2.

Table 1 . Annual emissions into the atmosphere per the unit of area of the country $\left[\mathrm{Mg} / \mathrm{km}^{2}\right]$

\begin{tabular}{|l|c|c|c|c|}
\hline \multicolumn{1}{|c|}{ Country } & Dust & $\mathrm{SO}_{2}$ & $\mathrm{NO}_{\mathrm{x}}$ & $\mathrm{CO}_{2}$ \\
\hline Poland & 7.68 & 12.61 & 4.73 & 1,472 \\
France & 0.69 & 2.80 & 4.33 & 184 \\
Japan & 1.70 & 2.87 & 3.76 & 641 \\
Germany & 2.30 & 8.19 & 12.30 & 824 \\
USA & 0.74 & 2.23 & 2.13 & 132 \\
Switzerland & 0.55 & 2.39 & 5.38 & 289 \\
Great Britain & 0.95 & 6.02 & 9.52 & 664 \\
\hline
\end{tabular}

Table 2. Economic losses arising from the emissions caused by fuel use [\%]

\begin{tabular}{|c|c|c|c|c|c|c|}
\hline \multirow{2}{*}{$\begin{array}{c}\text { Type of } \\
\text { pollution }\end{array}$} & \multicolumn{7}{|c|}{ Sector of economy } \\
\cline { 2 - 7 } & $\begin{array}{c}\text { Power } \\
\text { industry }\end{array}$ & Metallurgy & $\begin{array}{c}\text { Other } \\
\text { industries }\end{array}$ & $\begin{array}{c}\text { Municipal } \\
\text { Services }\end{array}$ & Transport & $\begin{array}{c}\text { Other } \\
\text { technologies }\end{array}$ \\
\hline $\mathrm{SO}_{2}$ & 25.5 & 2.0 & 5.8 & 11.2 & 1.2 & 6.2 \\
\hline $\mathrm{NO}_{\mathrm{x}}$ & 13.9 & 11.0 & 11.0 & 3.2 & 10.8 & 1.8 \\
\hline Dust & 2.4 & 0.5 & 1.7 & 2.8 & 0.0 & 0.0 \\
\hline
\end{tabular}

\section{Electric power production from biomass in the power plants}

Currently, the largest share in the energy production from renewable sources in Poland is generated by biomass which is an alternative, renewable energy source used to produce biofuels. The biomass itself may be used as biofuel, e.g. in the form of hay, wood, etc., or serve as the raw material for the production of other processed biofuels, e.g. rapeseed used in the production of biodiesel, potatoes or sugar cane in the production of bioethanol, or various organic materials, including waste, used to produce biogas.

In the power plants, various types of biomass are used in the production of electric power.

In the combined heat and power station in Białystok, one of the four power blocks with the capacity of $55 \mathrm{MW}$ is fitted with a modernized OP-140 boiler, used solely to fire biomass mainly in the form of wood waste from forest plantations and wood processing, to produce electric power and heat for the city. The annual electric power production capacity is $150,000 \mathrm{MWh}$. Figures from 1 to 5 illustrate the elements of the power block that uses biomass to produce electric power.

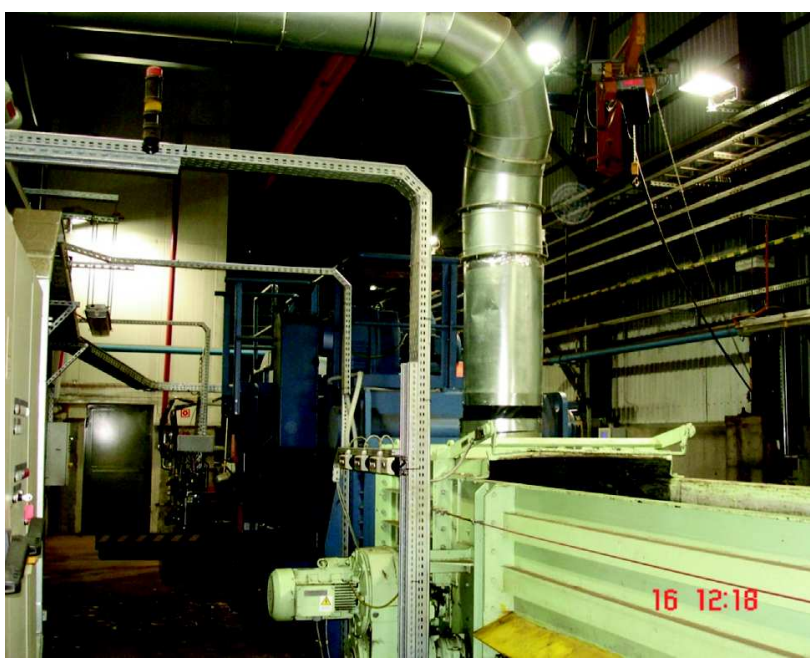

Figure 1. The system of feeding the biomass into the power block

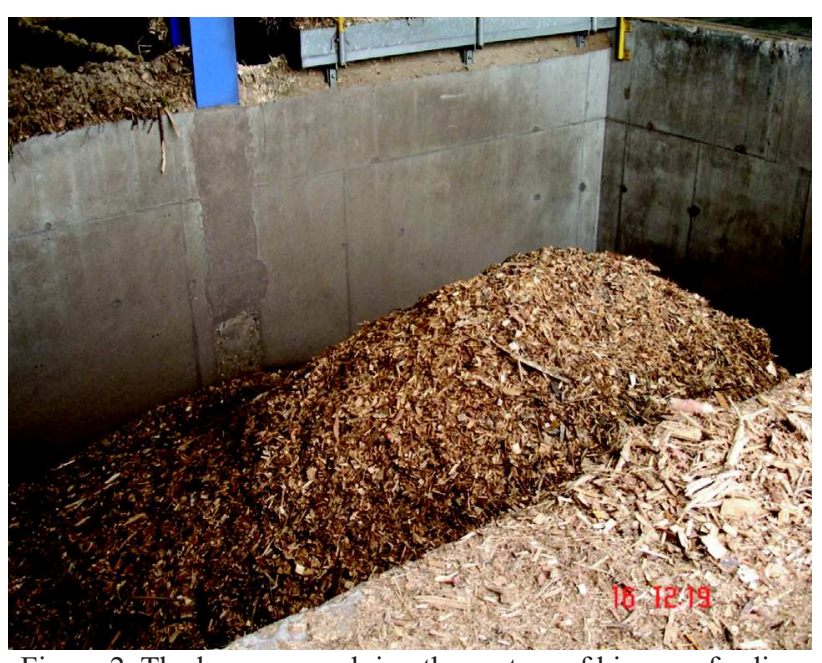

Figure 2. The hopper supplying the system of biomass feeding into the boiler

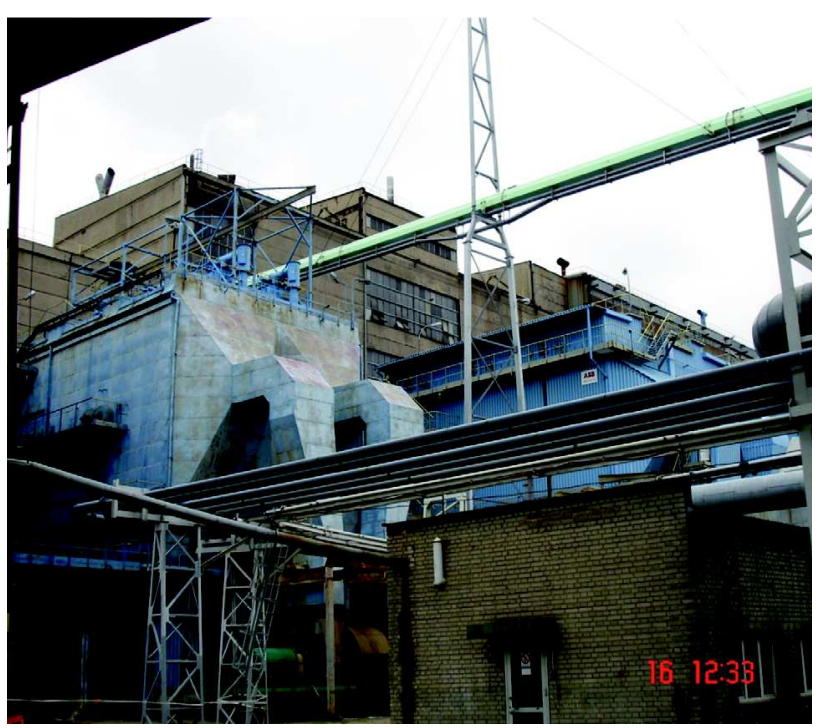

Figure 3. Power block fed with biomass 


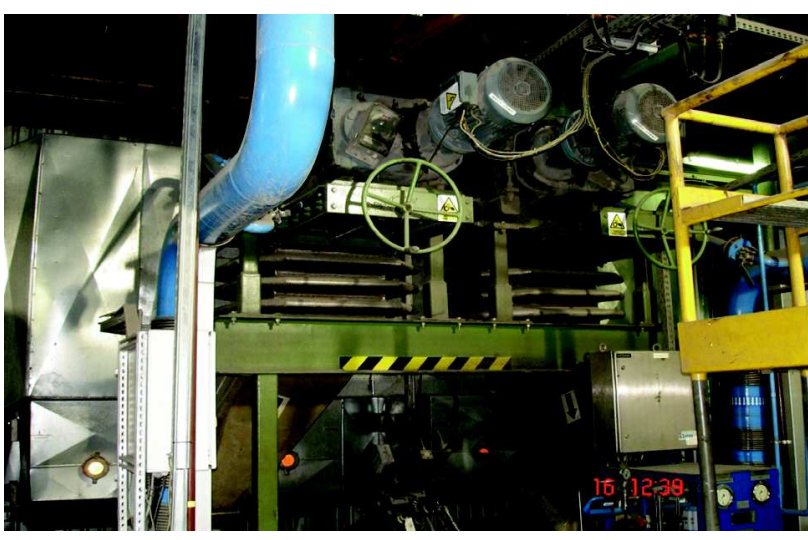

Figure 4 . The system of direct feeding of the boiler with biomass

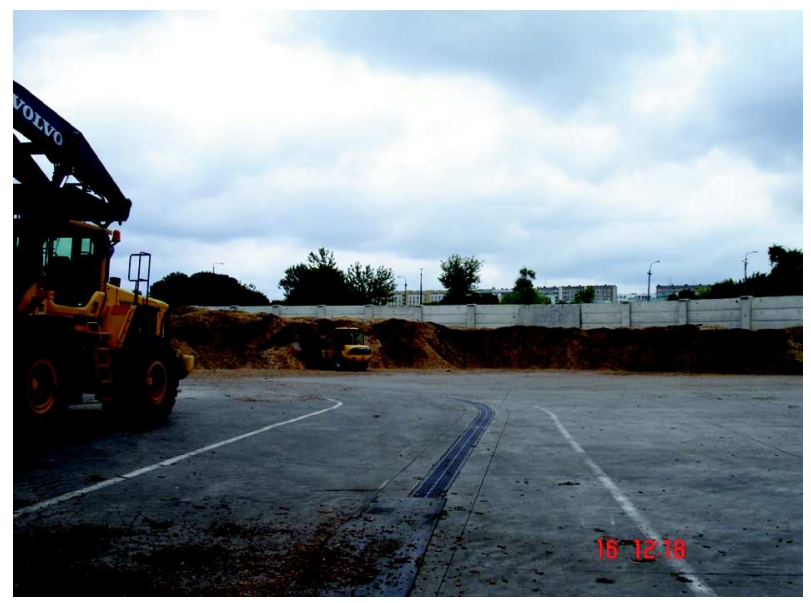

Figure 5. The storage yard for the biomass fed into the system supplying the power block.

In the power plant in Ostrołeka, one of the power blocks with the total capacity of $200 \mathrm{MW}$ is used to cogenerate electric power from co-firing of biomass and mineral coal. The biomass share in the process in $10 \%$ and the composition of the biomass is very diverse, including components from the forest plantations, agriculture and food industry, as well as from special energy crops. The system enables the annual additional production of the so-called "green electricity" in the capacity of ca. $86,000 \mathrm{MWh}$, at the same time reducing the emissions of carbon dioxide from fossil fuels by $60,000 \mathrm{Mg}$ due to the reduction of the coal consumption by $35,000 \mathrm{Mg}$, and reducing the emissions of sulphur dioxide by $300 \mathrm{Mg}$; the system uses ca. $65,000 \mathrm{Mg}$ of biomass. Figures from 6 to 9 illustrate the elements of the cogeneration system that uses biomass to produce electric power in the power plant.

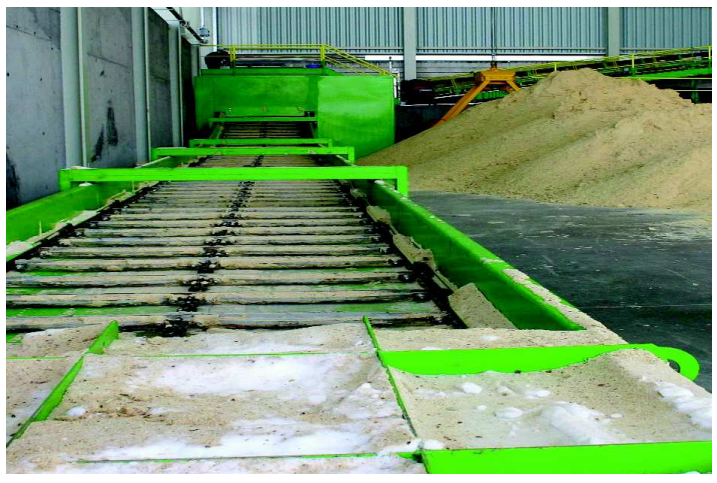

Figure 6. The biomass feeding system for the production of coal and biomass mixture for the cogeneration process.

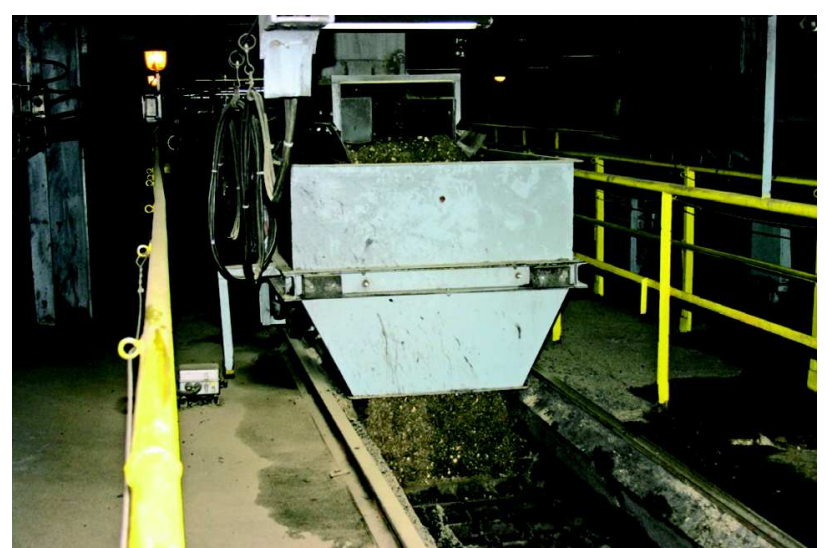

Figure 7. The system of boiler feeding with the coal and biomass mixture

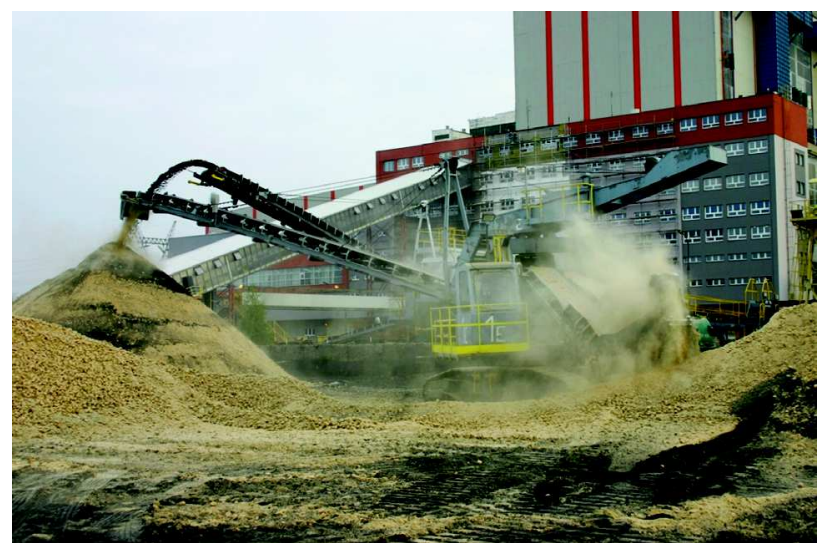

Figure 8. Production of the coal and biomass mixture for the cogeneration process

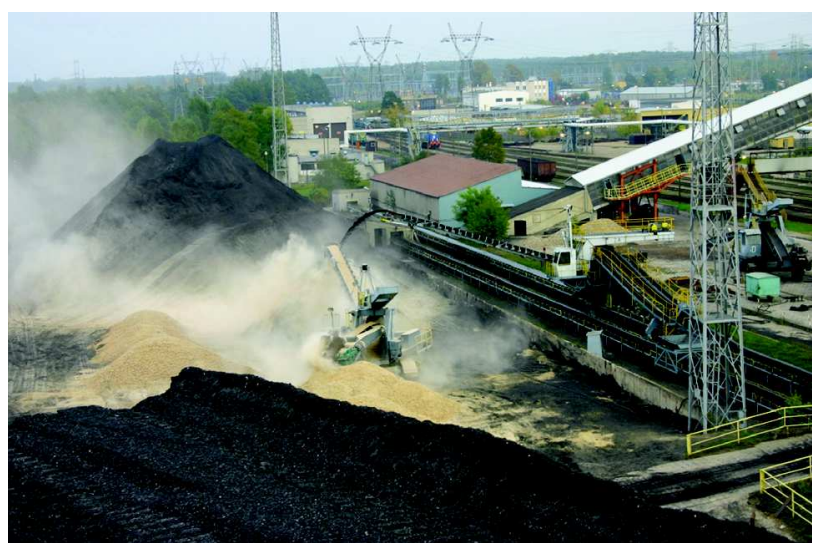

Figure 9. The storage yard for the coal and biomass for the production of the coal and biomass mixture for the cogeneration process

\section{Conclusion}

The production of electric power from biomass in the power plants has a number of advantages:

-it is environmentally friendly,

-it reduces the volume of waste, fly ash, slag, etc.,

-it allows the remains and waste from forest and agricultural production, and the food industry to be re-used,

- it increases the availability of energy from renewable sources, -it drives the development of the market of biomass of plant origin,

-it enables establishing energy crops that are exempt from the crop limits, 
-it drives the growth of small businesses in rural areas,

-it provides a steady recipient for the biomass suppliers.

The production of the production of electric power from biomass in the power plants also makes it possible to formulate a new strategy of using diverse energy sources to optimize the energy management in the national electric power system. The optimization of energy management in the electric power system balances the capacity for the electric power production from biomass with the available biomass resources and the consumers' demand.

\section{References}

[1.] Piechocki J., Neugebauer M., Solowiej P.: 2011. „Potencjał energetyczny odnawialnych źródeł energii i możliwości jego wykorzystania dla wybranego regionu województwa warmińskomazurskiego"; Inżynieria Rolnicza 3(128); s167-174, ISSN 1429-7264;

[2.] Sołowiej P., Nalepa K., Neugebauer M.: 2008. Analiza energetyczno-ekonomiczna produkcji energii cieplnej W kotłowniach na zrębki drewna. Inżynieria Rolnicza 2 (100) s.263268, ISSN 1429-7264.

[3.] Piechocki J., Sołowiej P., Neugebauer M.: 2011. „Przewidywane możliwości wykorzystania potencjału energetycznego odnawialnych źródeł energii dla wybranego regiony województwa warmińsko-mazurskiego". Inżynieria Rolnicza 5 (130), s. 237-242. ISSN 1429-7264. 